\title{
A EUCARISTIA E O CARÁCTER DIALÓGICO DA PALAVRA. PROPOSTA DE ABORDAGEM BAKHTINIANA
}

THE EUCHARIST AND THE DIALOGICAL NATURE OF THE WORD.

\author{
PROPOSING A BAKHTINIAN APPROACH
}

\begin{abstract}
ÂNGELO CARDita ${ }^{(*)}$
\section{RESUMO}

O estudo propõe uma aproximação à religião como fenómeno linguístico "dialógico" e concentra-se no exemplo da Eucaristia, por meio de uma análise dialógica da Oração Eucarística. Em preâmbulo, começa-se por estabelecer o estado da questão religiosa e teológica no pensamento e metodologia bakhtinianos, para propor, de seguida, um esboço de análise dialógica da Oração Eucarística. Demonstra-se que Bakhtin considera a Eucaristia como a mediação simbólica que põe em comunicação o evento-existir pessoal de Cristo com o eventoexistir pessoal de cada crente e, a partir da sua concepção dialógica do ato de palavra, avança-se com a possibilidade de reconhecer o poder da palavra divina no interior da palavra humana.

Palavras-Chave: Eucaristia. Oração. Análise dialógica. Bakhtin.
\end{abstract}

\section{ABSTRACT}

The study proposesan approach to religion as"dialogic" linguistic phenomenon and focuses on the example of the Eucharist, through a dialogic analysis of the Eucharistic Prayer. In the preamble, it begins by establishing the state of the religious and theological question in the Bakhtinian thought and methodology, to propose, then, an out line of dialogic analysis of the Eucharistic Prayer. Subsequently, the study shows that Bakhtin considers the Eucharist as the symbolic mediation which en acts the communication between the personal event-existence of Christ with the personal event-existence of each believer; and, from its dialogic conception of the speech act,it advances the possibility to recognize the power of the divine word within the human word.

KEYWORDS: Eucharist. Prayer. Dialogic analysis. Bakhtin.

\section{INTRODUÇÃO}

O objectivo deste estudo deve compreender-se na sequência dos movimentos de apropriação e, nesse contexto, de re-interpretação e atualização das perspectivas atribuídas a Mikhaïl Bakhtin e ao "círculo" por ele frequentado, para o estudo da linguagem. Trata-se, então, de propor uma aproximação à religião como fenómeno linguístico(e não apenas uma abordagem da questão da linguagem religiosa), mais exatamente, como fenómeno "dialógico". É neste sentido que me concentrarei no exemplo da Eucaristia, através de uma análise dialógica da Oração Eucarística. No entanto, a possibilidade de uma extensão da metodologia de inspiração bakhtiniana ao campo religioso não está desligada da

(*)Ângelo Cardita, doutor em teologia com a tese O Mistério, o Rito e a Fé: para uma "recondução antropológica” da teologia litúrgico-sacramental (Lisboa: Quimera 2007), é professor de teologia sacramental, liturgia e estudos rituais na Faculté de théologie et de sciences religieuses - Université Laval (Québec, Canadá). E-mail: angelo.cardita@ftsr.ulaval.ca 
eventual presença de um interesse religiosono próprio pensamento de Bakhtin ${ }^{1}$. Se, por um lado, esta questão se tem mostrado fecunda, pelo outro, ela levanta várias interrogações sobre o valor de Bakhtin para as ciências humanas. É preciso, portanto, estabelecer o estado da questão religiosa e teológica no pensamento e metodologia bakhtinianos, antes de propor um esboço de análise dialógica da Oração Eucarística.

\section{BAKHTIN DESMASCARADO?}

Os estudos bakhtinianos foram recentemente alvo de uma crítica demolidora, com a publicação do livro de Jean-Paul Bronckart e Cristian Bota, com o provocativo título: "Bakhtin desmascarado" (BRONCKART; BOTA, 2011). A intenção é clara: desmascarar o delírio coletivo que se teria apropriado de um grande número de académicos no âmbito da linguística e das ciências humanas ao se apresentarem como bakhtinianos, no estudo e desenvolvimento das intuições do pretenso sábio russo que, na verdade, se teria apropriado das obras de Volochinov e Medvedev (os verdadeiros estudiosos e únicos autores dos escritos que seriam depois atribuídos senão a Bakhtin, pelo menos ao "seu" círculo), aproveitando oseu desaparecimento prematuro. Para Bronkart e Bota, um tal círculo nunca terá existido de fato e mesmo que os escritos que se podem atribuir a Bakhtin revelem uma certa aproximação à intenção geral de contestar o estado da cultura e da ciência do ínicio do séc. XX, não chegam a fazer qualquer proposta coerente e sólida.

No contexto deste estudo, não me interessa diretamente o problema da autoria, mas somente os motivos que levam Bronkart e Bota a sublinhar a diferença entre os autênticos contributos científicos de Volochinov e Medvedev e as reflexões "mistificantes" de Bakhtin. O problema é que os primeiros escritos de Bakhtin possuiriamuma ontologia claramente religiosa que Bakhtin nunca teria abandonado, apesar de se ter tornado mais discreto nos escritos tardios. Eis o verdadeiro problema que incomoda os denunciadores suiços e que se transforma em critério de reconhecimento e atribuição de autoria dos textos discutidos. A presença de um pensamento de tipo religioso denuncia Bakhtin como autor de textos menores e de pouca importância, reabilitando Volochinov e Medvedev como autênticos e próprios autores, independentes de qualquer círculo de partilha e discussão cultural, metodológica e científica. A seguinte

\footnotetext{
${ }^{1}$ Sobre a questão teológica e religiosa, em Bakhtin: MIHAILOVIC, 1997, COATES, 1998, FELCH CONTINO,2001, BAGSHAW, 2013.
} 
citação de Bronkart e Bota a propósito dos primeiros escritos de Bakhtin é clara a este respeito:

Se estas reflexões colocam em evidência os temas duma certa teologia cristã, não é o seu estatuto teológico que nos importa aqui. Por agora, limitar-nos-emos a recordar e a sublinhar que, através de tais reflexões, Bakhtin pretende desenvolver uma proposta que seria ao mesmo tempo filosófica e científica e que esta pretensão altera radicalmente o estatuto das ideias que aí são mobilizadas. Não somente as ideias religiosas de Bakhtin são postas ao serviço de um projeto supostamente científico, como as ideias que ele toma (muito "livremente") da filosofia da sua época são por sua vez modificadas por esta referência místicoreligiosa. Se esta estranha mescla de metafísica, de raciocínios falaciosos e de linguagem filosófico-religiosa (nem propriamente teológica, nem propriamente filosófica) é dificil de situar, ela é no entanto muito próxima dos discursos ideologizantes de tipo sectário (BRONCKART; BOTA, 2011, p. 364).

Para Bronkart e Bota, ateologia não se pode misturar nem com a filosofia, nem com a ciência, na medida em que reflete e depende de uma "ideologia sectária”. Os autores suíços maravilham-secom o fato de que, em Bakhtin, ideias religiosas se possam colocar ao serviço de um projeto científico e fazem deste aspeto a marca de um pensamento sem qualquer pertinência ou valor epistemológico. No entanto, os discípulos e estudiosos de Bakhtin já sabiam disso, não vendo aí qualquer razão para denunciarou abandonar o "mestre", mas uma característica do horizonte axiológico do seu pensamento.

\section{OUTRO HORIZONTE AXIOLÓGICO}

Estudando as dimensõesfilosóficas do pensamento de Bakhtin, Maryse Dennes sublinha como Bakhtin deixa de considerar o conhecimento à maneira de Kant, a partir do sujeito, para abordá-lo a partir da obra, que é também objeto "estético" derivado da ação do sujeito. O interessante para o nosso propósito é que, segundo a autora, considerando o sujeito como "volição", Bakhtin o teria libertado do seu carácter de "substância" e de abertura à transcendência divina, para o situar no terreno social.

Bakhtin, seguindo nisto o neo-kantismo da escola de Marbourg, retém e privilegia o domínio da estética. Ele liberta-o da sua dependência em relação às condições prévias do conhecimento do mundo. Do mesmo modo, ele separa o domínio da prática da sua relação a uma transcendência divina e situa-o totalmente no âmbito social, este último tornando-se então detentor da sua própria finalidade (DENNES, 1997, p. 88).

Bakhtin pensa, então, o sujeito e a sua ação sob um horizonte de vida ligado à capacidade humana de se inserir na cultura através da obra ou da "ação responsável”. Mas às influências da filosofia ocidental, Bakhtin teria 
acrescentado um elemento ligado à tradição cultural russa: as suas raízes cristãs.

Assim, o enraizamento da cultura russa no cristianismo bizantino e na tradição patrística é encarado como a origem de um horizonte axiológico que se teria desenvolvido, não paralelamente à história cultural da Rússia, - como no caso do Ocidente -, mas no seu interior. A Rússia seria assim por ela mesma detentora de uma forma de ser que o Ocidente teria mantido à distância do seu progredir. As suas características seriam as da espiritualidade hesycasta: uma aproximação ao ser humano baseada não já sobre normas permitindo antes de mais o conhecimento do mundo, - tal como a substância com a prioridade dada tanto à causa final como à causa eficiente -, mas uma aproximação ao ser humano fundada sobre uma experiência da sua condição de criatura divina, destinada à divinização pela recepção das energias divinas e pela participação na encarnação (DENNES, 1997, p. 101).

Maryse Dennes não só reconhece a presença de marcas teológicas no pensamento de Bakhtin, como as valoriza na qualidade de indicadores do horizonte axiológico à luz do qual devemos ler e compreender Bakhtin. A separação do domínio da prática da sua relação com a transcendência divina que o situa por completo no âmbito social não nega a origem teológica e espiritual da visão antropológica assim desenvolvida. Pelo contrário, tal é possivel porque, contrariamente ao que aconteceu no ocidente, a história cultural do cristianismo e da teologia russos não conheceu a fratura epistemológica que opôs a razão à fé, antes progrediu na razão a partir da visão antropológica da fé, tal como destilada pela espiritualidade hesycasta: uma visão integral e participativa do ser humano que, uma vez, reencontrada no seu contexto social e histórico só pode reafirmar a autonomia sob a forma da responsabilidade, a liberdade sob a forma do diálogo e a identidade sob a forma da alteridade.

\section{O SENTIDO DIALÓGICO DA REVOLUÇÃO BAKHTINIANA}

A defesa apaixonada das perspectivas bakhtinianas pelo linguísta italiano Augusto Ponzio proporciona um último elemento a considerar em relação à “cripto-teologia” de Bakhtin. Para Ponzio, o coração das teses bakhtinianas reside na "dialogicidade" intrínseca de todo o ato de palavra². Este aspeto parece não ter qualquer relação com o problema religioso, a menos que o fundamento do carácter dialógico do discurso se encontre numa "filosofia moral"; e tal é o caso de Bakhtin.

\footnotetext{
2 «[...] a dialogicidade [...] é a dimensão constitutiva de qualquer ato de palavra, o discurso. Cada palavra se realiza em uma relação dialógica e é invadida pela palavra do outro; é sempre réplica de um diálogo explícito ou implícito e não pertence nunca a uma só consciência, a uma só voz» (PONZIO, 2013, p. 97).
} 
Os interesses originários de Bakhtin são pela filosofia moral, acima de tudo pelo problema da responsabilidade. [...]. A Bakhtin interessa a responsabilidade de como responder ao outro e pelo outro, sem álibi. Interessa mostrar que não o valor do eu, mas o valor do outro é esteticamente produtivo. Bakhtin ocupa-se da palavra para evidenciar nela a presença de uma palavra outra que a torna inteiramente dialógica [...] (PONZIO, 2013, p. 233).

É assim que, segundo Ponzio, a contribuição fundamental da filosofia da linguagem de Bakhtin consiste na inauguração de uma "crítica da razão dialógica”. É de sublinhar como, no recurso à filosofia moral dos primeiros escritos de Bakhtin, Augusto Ponzio não só define, como fundamenta o dialogismo bakhtiniano. O dialogismo não pode ser entendido no sentido banal do diálogo (como faz Todorov), nem como o intercâmbio entre duas identidades perfeitamente idênticas (como entende Holquist), ou ainda como a coexistência de vozes independentes que tendem para a objetividade do autor (como interpreta Wellek). Contudo, na sua defesa do carácter dialógico de todo o ato de palavra, do aspeto assimétrico da relação eu-outro e do alcance da exotopia bakhtiniana, Ponzio não se interroga sobre a possível relação desta forma de entender e de descobrir a polifonia e a dialogicidade linguísticascom o "evento da ativa abnegação" que, para Bakhtin, é representado pelo próprio Cristo e constitui mesmo uma referência fundamentalpara a sua forma entender o ato responsável e responsivo. Assim, a denúncia de Bronckart e Bota não desmascaria tanto as fraudes de Bakhtin, como o "delírio" de uma interpretação puramente sociológica da linguagem quando, na verdade, a proposta de Bakhtin pareceria ser a de uma releitura sociológica dos fundamentos religiosos $e$ teológicos da linguagem, tal como sugere Maryse Dennes.

\section{O EXEMPLO DA EUCARISTIA}

Augusto Ponzio ignora a referência ao evento de Cristo naFilosofia do ato de Bakhtin, debilitando assima defesa da filosofia da linguagem bakhtiniana, na medida, precisamente, em que esta depende da relação com a filosofia moral que a sustenta. Esta assenta em larga medida na referência ao exemplo da ativa abnegação de Cristo, tal como Bronckart e Bota se dão conta, sem poderem reconciliar as perspectivas linguísticas de Bakhtin com os seus interesses teológicos. Se o "desmascaramento" de Bronckart e Bota se referisse somente à paternidade e autoria de alguns textos, os argumentos de Ponzio poderiam ser eficazes, mas a denúncia toca também o "mascaramento" dos aspetos religiosos e teológicos das reflexões de Bakhtin, estratégia de que também Ponzio se serve, quando o melhor teria sido seguir pelo caminho de compreensão aberto por Maryse Dennes.Desta forma, baseando-se na relação da filosofia da linguagem 
de Bakhtin com a filosofia moral, Ponzio poderia referir-se sem se envergonhar ao evento único e exemplar de Cristo. Ora, o interessante é que, no mesmo contexto, Bakhtin não fala apenas de Cristo, mas também daEucaristia, símbolo da sua doação que prolonga a sua presença no mundo.

Uma empatia, o ser possuído, a perda de si, não têm nada em comum com a açãoato responsável do renunciar a si mesmo ou da abnegação: na abnegação eu sou maximamente ativo e realizo completamente a singularidade do meu lugar no existir. O mundo no qual eu, do meu lugar, no qual sou insubstituível, renuncio de maneira responsável a mim mesmo não se torna um mundo no qual eu não estou, um mundo indiferente, no que diz respeito ao seu sentido, à minha existência: a abnegação é uma realização que abraça o existir-evento. Um grande símbolo de ativa abnegação, Cristo que nos deixou, sofrendo na eucaristia, na doação de seu corpo e do seu sangue, uma morte permanente, permanece vivo e ativo no mundo dos eventos, mesmo quando deixou o mundo; é próprio de sua não-existência no mundo que nós vivamos reforçados em comunhão com ele. $\mathrm{O}$ mundo que Cristo deixou não poderá mais ser o mesmo, como se ele nunca tivesse existido: é, fundamentalmente, um outro mundo (BAKHTIN, 2010, p. 6364).

Bakhtin pretende explicar o carácter ativo da empatia no sentimento estético. A empatia não é uma passividade pura e total, mas algo que se vive ativa e conscientemente. Por isso, a empatia cria algo de novo, no encontro entre o sujeito e o objeto, influindo no carácter essencial da existência do mundo. A empatia pura é impossível, pois decretaria o fim da existência do sujeito na sua singularidade. É então que Bakhtin se refere ao supracitado exemplo de Cristo.

A afirmação final sobre a transformação do mundo corresponde ao que Bakhtin já tinha afirmado sobre a empatia, mas serve para reafirmar o imperativo da unidade singular do evento, revelando também a incapacidade da sua determinação por meio de categorias teóricas, históricas ou estéticas. A globalidade do evento inclui o fato histórico, o seu sentido (teórico e intuitivo) $e$ a nossa "participação respondente" no mesmo. Em princípio, a afirmação aplica-se tanto ao caso específico de Cristo como a qualquer ato de existir no mundo dos eventos. A partir daqui, o texto fala do evento do existir sem se referir a Cristo, mas a argumentação decorre do exemplo da abnegação de Cristo3.

\footnotetext{
3 Significará isto que tudo o que Bakhtin afirma sobre a singularidade do existir se pode aplicar também ao existir único, responsável e abnegado de Cristo? «Em Cristo encontramos a síntese, única pela profundidade, do solipsismo ético, do rigor infinito do homem consigo, isto é, de uma atitude irrepreensivelmente pura em face de si mesmo com a bondade ético-estética para com o outro: aqui, pela primeira vez, apareceu o eu-para-mim infinitamente profundo, não frio mas desmesuradamente bondoso
} 
A abnegação de Cristo é colocada em relação com a representação do seu sofrimento na Eucaristia, quer dizer, com a doação "simbólica" do seu corpo e do seu sangue, mais que (como se poderia esperar) com a sua doação "existencial" na cruz. Esta encontra-se certamente pressuposta, mas Bakhtin pensa, mais radicalmente, na nossa relação - pessoal e responsável - com o Cristo: "é próprio de sua não-existência no mundo que nós vivamos reforçados em comunhão com ele”. É o ponto de vista do sujeito responsável, que assume uma posição em relação ao evento-existir de Cristo nos seus efeitos sobre o mundo, que interessa a Bakhtin como confirmação do carácter ativo da abnegação. Bakhtin retira, portanto, uma consequência existencial do fato da permanência simbólica da morte de Cristo na eucaristia. Bakhtin lê o símbolo eucarístico à luz do acontecimento real que ele representa tanto em relação a Cristo (a sua morte na cruz como consequência da abnegação ativa que caraterizou toda a sua vida) como em relação a cada um de nós, chamados à responsabilidade na nossa própria vida. Desta forma, Bakhtin considera a Eucaristia como a mediação simbólica que põe em comunicação o evento-existir pessoal de Cristo com o evento-existir pessoal de cada crente "em comunhão com ele". É assim, também, que Cristo "permanece vivo e ativo no mundo dos eventos, mesmo quando deixou o mundo": simbolicamente, na eucaristia; existencialmente, no evento-existir responsável e abnegado de cada crente (que entra em comunhão com o evento-existir de Cristo através dos símbolos eucarísticos).O evento da vida e da morte de Cristo chega assim à sua plenitude como fato e sentido no mundo ao mesmo tempo em que o transforma radicalmente: “é, fundamentalmente, um outro mundo". O ato-responsável deixa sempre marcas que o perpetuam no mundo.

\section{PALAVRA Divina E PALAVRA HUMANA}

Uma leitura bakhtiniana da religião é, pois, não só uma possibilidade de aplicação das perspectivas e categorias do sábio russo a um campo específico da experiência humana, como, talvez, a tarefa pendente capaz de injetar lucidez tanto ao delírio de uma pura redução sociológica da filosofia da linguagem, como ao delírio de uma fundamentação linguística sem qualquer referência ao seu contexto social. No âmbito religioso, o problema traduz-se, hoje, na rutura entre a teologiae as ciências humanas (ou ciências das religiões). Estas estudam os fatos religiosos nas suas dimensões imanentes (históricas, sociais,

com o outro, que faculta toda a verdade ao outro como tal, revela e afirma toda a plenitude da originalidade axiológica do outro» (BAKHTIN, 2006, p. 52). 
psicológicas, linguísticas) como uma filosofia da linguagem de pendor sociológico estuda os atos de fala humanos. Já a teologia tende a dedicar-se à fundamentação "transcendental" da fé religiosa, deixando para segundo plano os seus aspetos "categoriais". A teologia assemelha-se assim a uma filosofia da linguagem que prescinde do contexto social real e das suas influências nos atos de fala. Se todo o fenómeno humano é também um fenómeno linguístico, então, no estudo dos fenómenos humanos, temos que passar necessariamente pela sua reflexão/refração linguística em atos de fala bem concretos. Neste sentido, a teologia e as ciências humanas repartem as suas competências no âmbito linguístico a partir da dicotomia saussuriana: a teologia assume o mundo da parole para falar da revelação de Deus, da encarnação do Verbo e do anúncio da salvação, enquanto as ciências humanas dominam o mundo da langue, dedicando-se às trocas linguísticas, às condições e marcas que acompanham os vários discursos (económicos, políticos, ideológicos), assim como aos problemas de comunicação, tradução e interpretação entre eles. Nesta repartição de competências, no entanto, a teologia não é capaz de mostrar como e porque razão a palavra divina surge e se comunica sempre e só como palavra humana (ou seja, como langue), enquanto as ciências humanas não conseguem propôr vias de fuga para o ciclo infinito das trocas linguísticas, reconhecendo apenas que o ser humano é tanto produto como produtor da linguagem (que é assim, finalmente, conotada com a parole).

Para Bakhtin, não existe a oposição langue/parole, mas cada ato de palavra é dialógico, plural, polifónico.Portanto, uma aplicação religiosa e teológica da filosofia da linguagem bakhtiniana parece destinada a reconciliar as expressões linguísticas religiosas com as experiências linguísticas humanas, num movimento semelhante ao da passagem da criação do mundo e do ser humano pela palavra divina (Gn 1) à encarnação do Verbo (Jo 1), quer dizer, a passagem do reconhecimento do poder criador da palavra divina ao reconhecimento do poder criativo do palavra humanasem as contrapor,nemconfundir. Não se trata apenas de compreender a dimensão performativa da palavra humana, mas, mais radicalmente, de reconhecer $o$ poder da palavra divinano interior eem diálogo com a palavra humana. É por este motivo que escolho para análise a Oração Eucarística.

No séc. IV, Ambrósio de Milão explicava aos seus catecúmenos que se Deus tinha criado o mundo com o poder da sua palavra, nada havia de espantoso que a mesma palavra divina pudesse transformar o pão e o vinho no corpo e no sangue de Cristo. Agostinho de Hipona, o mais famoso dos alunos de 
Ambrósio, definiria o sacramento como o encontro da palavra com o elemento: accedit verbum ad elementum et fit sacramentum. Com esta breve fórmula se propunha também àteologia uma compreensão linguística do evento sacramental, tendo como modelo, muito particularmente, a citação das palavras de Jesus na sua última ceia com a ordem da reiteração ritual: "fazei isto em memória de mim". Muito expressivamente, a Igreja não sabe "fazer" o que Jesus mandou sem voltar a "dizer" as suas palavras. Na Eucaristia e nos sacramentos, estamos assim diante de um caso particular de performatividade linguística:particular porque na voz humana ressoa a voz divinae ainda porque o contexto intencional do ato de fala sacramental é explicitamente dialógico. Na Oração Eucarística, o diálogo entre o ministro e os fiéis depende do diálogo entre Deus e a humanidade, quer dizer,o diálogo entre a Igreja e Deus dá-se no interior do diálogo de Deus com a humanidade. Os atos de fala sacramentais, particularmente a Eucaristia, são, pois, atos de fala intrinsecamente dialógicos (na voz humana ressoa a voz divina que com ela entra em diálogo) que se fundam na mais assimétrica das relações eu-outro, ou seja, na relação nunca objetivável com o outro transcendente, introduzindo no mundo uma exotopia tão profunda quanto radical, na sua diferença, mas que se dá e só se pode dar no interior da experiência humana da linguagem.Na reprise sacramental das palavras de Cristo, na Oração Eucarística, não se trata apenas de um caso de "intertextualidade", mas da revelação do carácter dialógico da palavra - de toda a palavra - e, em definitivo, da vida autenticamente humana.

\section{NOTAS PARA UMA ANÁLISE DIALÓGICA DA ORAÇÃo EUCARÍSTICA}

Na liturgia romana atual, há várias Orações Eucarísticas que se juntaram ao tradicional Canon Romano. Exceptuando este, que não sofreu senão pequenas revisões de estilo, as Orações Eucarísticas da liturgia romana possuem os mesmos elementos literários, organizados numa estrutura própria:

a) Diálogo inicial: O Senhor esteja convosco - Ele está no meio de nós...

b) Prefácio: ...é nosso dever e salvação dar-vos graças...

c) Santo

d) Epiclese I, sobre os dons: Santificai, pois, estas oferendas...

e) Memorial, com as palavras de Cristo na última ceia: ...Fazei isto em memória de mim, concluindo com a aclamação da assembleia: Anunciamos, Senhor, a vossa morte...

f) Ofertório: ....Nós vos oferecemos, ó Pai...

g) Epiclese II, sobre a Assembleia: ...sejamos reunidos pelo Espírito Santo num só corpo. 
h) Intercessões: Lembrai-vos, ó Pai, da vossa Igreja...

i) Doxologia final: Por Cristo, com Cristo, em Cristo... com a resposta de ratificação da Assembleia: Amen.

Tendo em conta que as duas epicleses formam uma unidade, podemos considerar três grandes seções na Oração Eucarística:

1) Seção introdutória, que apresenta os motivos da ação de graças e desemboca na aclamação Santo;

2) Seção epiclética, que invoca o Espirito Santo para que, atuando com as palavras de Cristo, transforme os dons e toda a Assembleia no Corpo de Cristo;

3) Seção predicativa e doxológica final.

No quadro abaixo, apresento as relações dialógicas que se estabelecem entre o Presidente da celebração, a Assembleia litúrgica e as pessoas divinas, durante a Oração Eucarística, segundo os seus elementos literários próprios e seções fundamentais4.

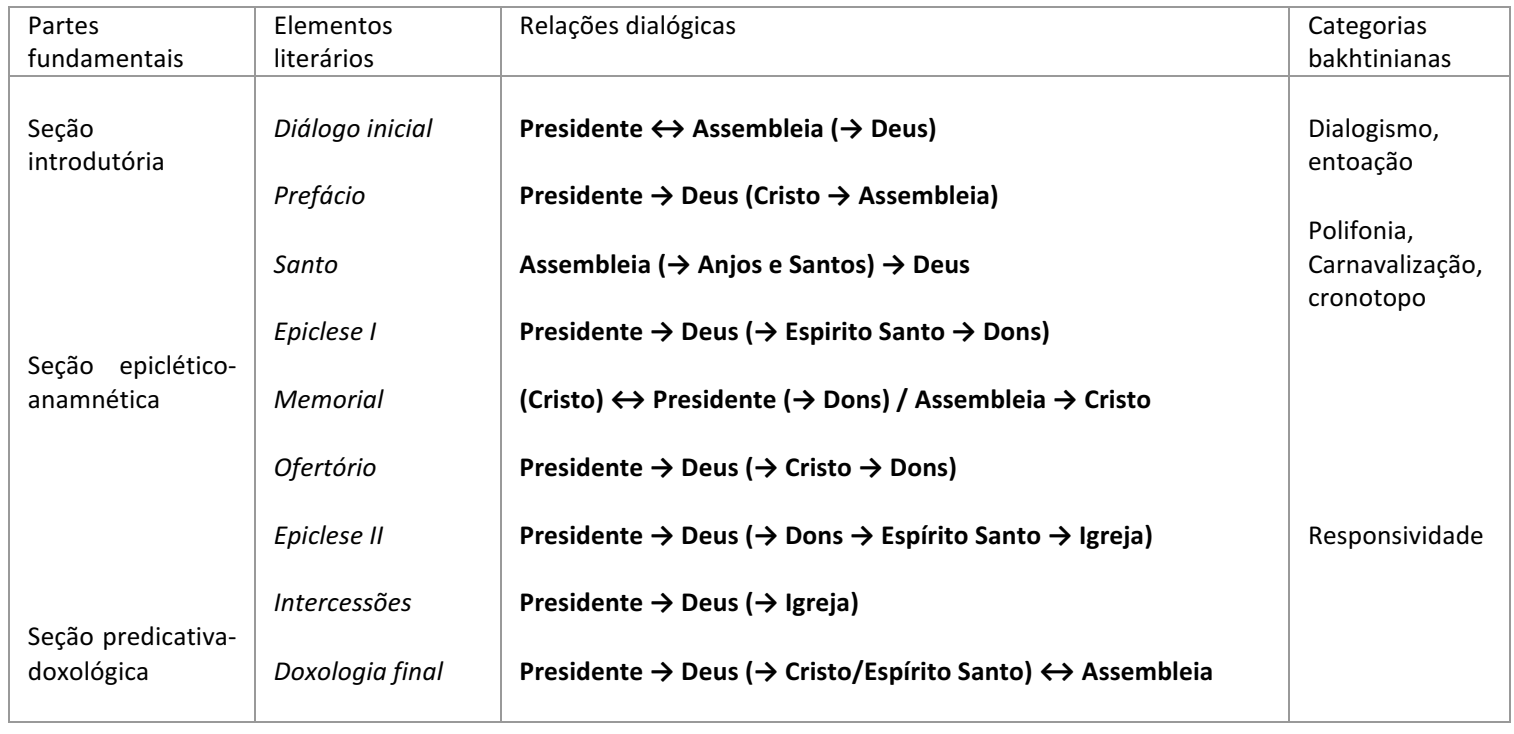

4 A presente análise refere-se diretamente à Oração Eucarística II do Missal Romano, que resulta da adaptação da "proto oração eucarística" da Tradição Apostólica (atribuída a Hipólito de Roma) segundo o modelo ou a estrutura antioquena, completada para harmonizar-se com a tradição do Cânone Romano e enriquecida com uma primeira epiclese de consagração, à semelhança do modelo alexandrino. 
No diálogo inicial, o Presidente não toma a palavra como se ela fosse um objeto, mas ele deve suscitar a réplica da Assembleia, a qual se recusa igualmente a apoderar-se da palavra como coisa sua, devolvendo-a ao Presidente. A palavra não pertence a ninguém, mas é sempre livre e está sempre em circulação, manifestando a presenca de Deus no espírito humano e convidando a voltar-nos para Deus para entrar em diálogo com ele. O diálogo com Deus emerge assim do diálogo comunitário e não se pode confundir com um solilóquio interior. É preciso sublinhar que, ao longo da Oração Eucarística, o Presidente não se situa sempre numa posição de enunciação principal. Ele é retirado desta posição pelas intervenções da Assembleia que confirmam e dão uma referência comunitária concreta aos atos de fala do Presidente. Durante o prefácio, o Presidente parece esquecer a presença da Assembleia, passando a dirigir-se a Deus.Não podemos, contudo, separar o prefácio do Santo e, portanto, é preciso reconhecer que o diálogo com Deus não exclui a voz da Assembleia e, na verdade, dos santos e dos anjos e mesmo de todaa criação:"o céu e a terra proclamam a vossa glória”. Trata-se, pois, de uma grande polifonia “cósmica” na unanimidade das vozes.

A seção epiclética prolonga omesmo dinamismo, mas visa agora a presença e a ação de Cristo e do Espírito Santo. Se a presença de Cristo está ligada às palavras que fazem o sacramento, a ação do Espírito Santo, que se exprime também pelos gestos (mãos estendidas e sinal da cruz sobre os dons), não concerne menos à transformação dos dons assim como à unidade do Corpo de Cristo, quer dizer, a comunhão eclesial. O presidente é agora deslocado da posição de enunciador pela irrupção, no coração do discurso anamnético, da voz e dos gestos do próprio Cristo“estando para ser entregue”. Uma tal irrupção é fundamental não apenas por causa do seu carácter exotópico, mas principalmente porque ela é a palavra sagrada que explica e justifica a ação ritual, na obediência à ordem "Fazei isto em memória de mim" que manifesta o poder da palavra na repetição ritual. Nesta irrupção dialógica, o carácter performativo da palavra e a dimensão eloquente dos símbolos litúrgicos interpenetram-se no seu encontro sacramental, ligando, através da oração de ação de graças (eucaristia) que dá nome ao conjunto da ação ritual, a Mesa Eucarística à Mesa das Escrituras, a comunhão sacramental à escuta do 
Evangelho, «num só ato de culto»5,porque nelas é sempre a voz de Cristo que ressoa e a sua presença que se manifesta ${ }^{6}$.

Na seção doxológica final, as intercessões desenvolvem a referência à comunhão introduzida pela segunda epiclese, abrindo a Assembleia à comunhão universal: a comunhão entre as igrejas locais particulares e a comunhão com os defuntos e os santos. Através das preposições (por, com, em) que assumem aqui um valor teológico e um valor gramatical, na doxologia, a oração de intercessão transforma-se em louvor trinitário. Não se poderia sublinhar melhor a importância dialógica do amenque conclui e ratifica a Oração Eucarística senão recordando como alguns Padres da Igreja estavam dispostos a recomeçar a oração desde o início se esta resposta finallhes parecesse débil. Por outras palavras, sem uma resposta adequada julgava-se que a oração não tinha chegado ao seu primeiro destinatário.

Em tudo isto é necessário considerar ainda a importância da entoação ou da carga emotivo-volitiva dos enunciados. O convite que abre o diálogo é uma expressão do desejo e da certeza da presença do Senhor, reforçada pela exortação a elevar os corações para que a ação de graças seja digna e justa, permitindo a união da voz dos fiéis às vozes dos anjos e dos santos. Cada elemento literário da Oração Eucarística possui a sua carga afetivo-volitiva própria, de tal modo que não só o êxito do ato de fala depende da entoação dada, como a entoação com que efetivamente se enuncia o discurso é o primeiro indicador do sentido e da força do ato de fala eucarísticos tanto do Presidente como de toda a Assembleia.

A presença daquilo a que Bakhtin chama carnavalização é igualmente relevante: no Santo, não são já as pessoas que formam a Assembleia que cantam ou rezam, mas os anjos e os santos, o céu e a terra. Por sua vez, no memorial, é o próprio Cristo que fala e age, para que, finalmente, se manifeste o Corpo de

\footnotetext{
5 Concílio Vaticano II, Constituição Sacrosanctum Concilium, 56.

6 Os textos litúrgicos estão impregnados de "intertextualidade" bíblica e, portanto, a liturgia está em constante diálogo com a Bíblia, reconduzindo-a à sua condição oral original e originante. Já na saudação que lança o diálogo inicial "O Senhor esteja convosco" se podem encontrar ressonâncias das saudações litúrgicas que São Paulo reproduz em algumas das suas cartas e até um eco da própria saudação do Ressuscitado “A paz esteja convosco”. Para cada enunciado da Oração Eucarística é possível encontrar toda uma rede dialógica e intertextual bíblica, no entanto, a reprise das palavras de Cristo na última ceia têm um lugar e uma importância particulares na medida em que estabelecem a ponte entre a oração litúrgica e a narração bíblica, o sacramento e o acontecimento pascal, o sacrifício da Igreja e o sacrifício de Cristo.
} 
Cristo em todo o seu mistério, não só no pão e no vinho, mas na própria Assembleia7.

A Oração Eucarística possui ainda vários aspetos ligados ao cronotopo, ou seja, à coexistência e transformação do espaço e do tempo: no Santo, entoação, carnavalização e polifonia unem-se para formar um novo cronotopo que substitui o cronotopo do aqui e agora, pelo cronotopo do reino dos céus e da eternidade. No memorial, somos transpostados para o cronotopo da última ceia, o qual, mediante a aclamação une o cronotopo do mistério pascal (morte e ressurreição) ao cronotopo escatológico do regresso de Cristo: "Vinde, Senhor Jesus!". No memorial entra-se, pois, no cronotopo do mistério da fé. Nas intercessões, o cronotopo da Assembleia concreta, reunida num determinado espaço durante um certo período de tempo, dá lugar ao cronotopo da Igreja universal do passado (defuntos e santos) e do presente, abrindo-a ao cronotopo escatológico da plena comunhão com Deus, antecipado já pelo louvor e pela glorificação (portanto, em relação com uma certa entoação dos enunciados).

Finalmente, o apelo a uma responsividade responsável aparece muito particularmente na segunda epiclese, onde se pede a unidade no Corpo de Cristo, assim como nas intercessões, quando se implora que a Igreja "cresça na caridade”.

A referência ao ato concreto e singular completa-se, numa análise bakhtiniana, com o cruzamento do olhar "oficial" com interpretações "nãooficiais" ou, talvez melhor, "populares”. Assim, para dar apenas dois exemplos, podemos mencionar a tendência em certas comunidades de inserir um canto de veneração (eucarística ou até mariana) na parte anamnética, em substituição ou paralelamente à aclamação cristológica prevista, ou ainda a possibilidade aberta por alguns padres de se inserirem preces espontâneas e pessoais no momento das intercessões. O olhar oficial verá aqui apenas abusos a corrigir, enquanto um olhar dialógico poderá considerar estes fenómenos como tentativas de articulação de vozes ainda silenciadas. Um canto de adoração eucarística ou mariana pode significar que a linguagem da teologia oficial ainda está muito afastada das expectativas religiosas do povo e que a solução de um tal "abuso" não passa tanto pela imposição monológica da voz oficial, por mais ortodoxa

\footnotetext{
7 O termo carnavalização, em Bakhtin, não corresponde ao carnaval, embora não esteja dele desligado, mas ao carácter subversivo da festa e do riso. A Eucaristia e toda a liturgia cristã são "carnavalescas" em relação à figura caduca do mundo, na medida em que antecipam os "novos céus e a nova terra", a partir da transformação de elementos naturais e de situações humanas em símbolos da graça e da presença do Ressuscitado.
} 
que ela seja, quanto pelo incremento do próprio dialogismo da Oração Eucarística $^{8}$. Por sua vez, a possibilidade de juntar orações pessoais que decorrem da própria vivência das pessoas pode reforçar o carácter dialógico da Oração Eucarística, educando para a oportunidade e necessidade da presença singular da voz de cada um na voz do conjunto, abrindo, ao mesmo tempo, a Oração Eucarística às necessidades e problemas reais vividos pelas pessoas.

\section{CONCLUSÃO}

Nesta breve análise, cujo principal objetivo consistiu em ilustrar a pertinência das perspectivas bakhtinianas ou dialógicas no âmbito religioso, concentrei-me numa versão atual da Oração Eucarística, sem me referir a problemas de tradução e de transposição cultural (ou inculturação). No entanto, sustento que o dialogismo é capaz de dar conta destes aspetos de uma forma pertinente e adequada. Em cada palavra e expressão da atual Oração Eucarística ressoam também palavras e significados da berakah judaica, que depois foram traduzidos para o grego, mais tarde para o latim e mais recentemente para as línguas vernáculas. Em cada tradução, há também uma transposição cultural: da berakah judaica para o symposium grego e depois para o cultus publicus romano, as mesmas palavras vão-se enriquecendo e tornando cada vez mais dialógicas. Assim, nas Orações Eucarísticas de hoje não ressoa apenas a voz transcendental de Cristo, mas também a voz histórica da Igreja, com as suas tensões culturais, sociais, teológicas e espirituais. No entanto, a questão da transposição cultural não se coloca apenas diacronicamente, mas também sincronicamente. Deste modo, a Oração Eucarística, "fonte e cume" do sacrifício cristão, entra hoje em diálogo com outras realidades culturais religiosas, em constante transformação num contexto plural. Da mesma forma que certas marcas históricas permaneceram em algumas palavras sagradas (amen, hossana) e em alguns gestos rituais, será que as Orações Eucarísticas do futuro acolherão marcas linguísticas do atual diálogo do cristianismo com outras religiões e culturas?

\footnotetext{
8 Esta é, contudo, uma operação muito delicada, como se pode verificar no Brasil. Apesar de ser o único pais onde todas as Orações Eucarísticas do Missal Romanocontam com aclamações da Assembleia que as acompanham e, portanto, estruturamna íntegra, nem por isso deixam certas comunidades de acrescentar cantos devocionais de adoração durante a Oração Eucarística. Para uma proposta pastoral que conflui no sentido "dialógico" aqui proposto, ver GELINEAU, 1995.
} 


\section{REFERÊNCIAS}

BAGSHAW, Hilary B.P. Religion in the Thought of Mikhail Bakhtin. Reason and Faith.Aldershot: Ashgate, 2013.

BAKHTIN, Mikhail M.O autor e a personagem na atividade estética.In:ID., Estética da criação verbal. São Paulo: Martins Fontes, 4. ed., 2006,p. 3-192.

BAKHTIN, Mikhail M. Para uma filosofia do ato responsável. São Carlos: Pedro \& João, 2010.

BRONCKART, Jean-Paul - BOTA, Cristian. Bakhtine Démasqué. Histoire d'un menteur, d'une escroquerie et d'un délire collectif, Genève: Droz, 2011.

COATES, Ruth.Christianity in Bakhtin: God and the Exiled Author. Cambridge, New York - Melbourne: Cambridge University Press, 1998.

DENNES, Maryse. Bakhtine, philosophe?. In:DEPRETTO, C. (ed.).L'héritage de Bakhtine.Bordeaux: Presses Universitaires de Bordeaux, 1997, p. 79-105.

FELCH, Susan M. -CONTINO, Paul J. (ed.).Bakhtin and Religion. A Feeling for Faith.Evanston, Illinois: Northwestern University Press, 2001.

GELINEAU,Joseph.La prière eucharistique comme action de l'assemblée. Vint-cinq ans de recherches et d'expériences sur la célébration de la prière eucharistique dans la messe romaine après Vatican II. In:DE CLERCK, Paul et al.Vincolo di carità. La celebrazione eucaristica rinnovata dal Vaticano II.Bose-Magnano: Qiqajon, 1995, p. 141-158.

MIHAILOVIC,Alexandar.Corporeal Words: Mikhail Bakhtin's Theology of Discourse.Evanston, Illinois: Northwestern University Press, 1997.

PONZIO, Augusto. No Círculo com Mikhail Bakhtin. São Carlos: Pedro \& João, 2013. 